\title{
STRATEGY FOR THE DEVELOPMENT OF STATE-OWNED BUSINESS ENTITIES IN SUPPORTING THE FULFILLMENT OF ALUSISTA TO INCREASE NATIONAL RESILIENCE
}

\author{
Hotler Bachtera Danny*, Dhiana Puspitawati, Moeljadi, Tjahjanulin Domai \\ University of Brawijaya, Malang, Indonesia \\ *E-mail: danny3993bachtera@gmail.com
}

\begin{abstract}
In accordance with the mandate of the Defense Industry Law, State-Owned Enterprises can act as Lead Integrator of the National Alutsista PT. PAL Indonesia (PT. PAL) is one of the state-owned enterprises (BUMN) engaged in the construction of the Indonesian Navy Warships. The problem in this research is how the development strategy of PT. PAL as a BUMN in an effort to fulfill the national defense equipment to improve national resilience. The purpose of this study is to identify several internal and external factors that influence decision making and then determine the priority of strategic criteria and develop a strategic plan for the development of PT. PAL to be implemented in order to increase national resilience by fulfilling the national defense equipment. The research method used is a combination of qualitative and quantitative methods with the integration of SWOT analysis. The results showed that PT. PAL's problem solving was carried out through efforts to improve the competence of Human Resources (HR) and production facilities in the form of facilities and infrastructure. Human Capital Building policies and programs must continue to be socialized and internalized to improve the skills of employees to suit the demands of the times. An assessment of PT. PAL has been carried out by the Ministry of BUMN in 2017 based on the $\mathrm{KPKU}$ as a measuring tool; the results obtained by PT. PAL include BUMN category/level band good performance with a score of 489 .
\end{abstract}

\section{KEY WORDS}

Alutsista, development strategy, national resilience, SWOT.

Based on the Law of the Republic of Indonesia Number 16 of 2012 concerning the Defense Industry, it is explained that the defense industry is a national industry consisting of state-owned enterprises and privately-owned enterprises, either individually or in groups determined by the government to partially or wholly produce defense and security equipment, maintenance services to meet strategic interests in the field of defense and security located in the territory of the Unitary State of the Republic of Indonesia.

Indonesia has several defense industries which are expected to support the needs of the main weapon system equipment (defense equipment) needed by the TNI. The implementation of the TNI's main tasks is in dire need of qualified and capable defense equipment with modern technology and has a deterrence effect. Gradually, Indonesia will increase the defense budget to build national defense capabilities that have deterrence standards and exceed the Minimum Essential Force (MEF) level which is adjusted to the defense budgeting policy (Djarwono, 2017). To realize this, a defense industry is needed that is able to support all the needs of the TNI's defense equipment for the purposes of national defense independently. Indonesia as a large nation with a fairly wide territorial area and a large population, it is proper to have independence in various fields, including the field of defense equipment, both defense equipment and non-defense equipment (Hartanto, 2013).

Optimizing the capabilities of existing Government-Owned Enterprises (BUMN) is a step that needs to be taken in order to move towards national independence. In this world, there is no country where $100 \%$ of its defense equipment is supported from within. Each country has a specific policy in determining the types of defense products in order to have high competitiveness in the region and even in the world. On average, the problems faced by these SOEs are almost the same and all of them have not been able to become market 
leaders of the country's foreign exchange earners. Several national defense industries and state institutions owned by Indonesia include PT.Dirgantara Indonesia (PT. DI), PT. Len, PT.Pindad, LIPI, BPPT, LAPAN, PT.DokKodjaBahari, PT. PAL Indonesia and others. PT. DI has produced CN-295 aircraft, PT. Len has produced CMS (Combat Management System), PT.Pindad has produced various types of ammunition, tanks and rocket launcher vehicles, LIPI has developed the ISRA Coastal Radar, BPPT has developed UAVs, Lapan has developed $122 \mathrm{~mm}$ rockets, PT.DokKodjaBahari built the BCM-122 ship, and PT. PAL built the Republic of Indonesia Warship (KRI) including the Submarine, the Missile Destroyer Ship (PKR)-105, the Landing Platform Dock (LPD)-125 and the Missile Fast Ship (KCR) -60.

Most of the Navy's defense equipment, especially $\mathrm{KRI}$, is still produced from foreign shipyards. In accordance with the mandate of Law No. 16 of 2012, PT. PAL is slowly but surely trying to meet the needs of the Navy's defense equipment. In collaboration with the South Korean shipyard Daewoo Shipbuilding \& Marine Engineering (DSME), PT. PAL produces the DSME1400 class submarine, namely Diesel Electric submarine with the joint production method (Sarjito, 2018). This product is a form of commitment to Law no. 16 of 2012 with the transfer of technology (ToT) method. In this way, it is hoped that PT. PAL can build submarines independently. PT. PAL Indonesia has complete infrastructure and facilities to support business activities, namely infrastructure built on an area of 23 hectares. In the area of the company, various infrastructure and facilities that are quite modern have been built, but they still have not resolved the problems faced by PT. PAL so that several activities are not delayed, including the submarine construction project. In addition to delays in delivery, some of PT. PAL's productions are also not in accordance with the specified operation requirements and technical specifications.

The problems faced by PT. PAL Indonesia are caused by several things including the problem of HR (Human Resources) and infrastructure (facilities). Currently, PT. PAL is still an industrial category that is still under the SOE revitalization program. The plan is that the company's condition will be restored according to its designed capacity. Therefore, improvements are needed in various fields so that PT. PAL is able to increase the competitiveness of the quality of the products produced and encourage the fulfillment of domestic defense equipment needs, which will then create independence in the development of the defense industry. In addition, the delay in delivery experienced by PT. PAL can be found the right solution by limiting some shipbuilding work that has not been fully mastered, so that it will help PT. PAL in fulfilling the work according to the contract. Some of the shipbuilding works that have been completely mastered include the construction of LPD (Landing Platform Dock) ships which have successfully entered foreign markets, which were purchased by the Philippine Navy. However, some ship constructions are still problematic, such as the construction of submarines, the construction of Fast Missile Ships (KCR) and others. To overcome this, PT. PAL must reduce the construction of ships that have the potential to be problematic in shipping and build ships that are already fully mastered by the technology and will not have problems in terms of delivery.

In a study written by Eko Krisdiono, using a combination of qualitative and quantitative methods, the output generated from this research is a strategic step to empower coastal areas which is the main task of the Navy. The results obtained show that it is important to empower the area in Sendangbiru to increase national resilience, the analysis used is SWOT, ISM, BSC (Krisdiono, 2019). In connection with some of the descriptions above, it is important to have an in-depth analysis to Increase National Resilience", which has never been studied by anyone before. The approach used in this research is the integration of SWOT.

This paper has many literatures to support the research, such as literature with title Indonesian Defense Industry model Concept: A Study Framework for Defense Industry Building(Hartati \& Muhammad, 2014), Civil Participation in Military Innovation: Cooperation between the Defense Industry of Indonesia and Turkey 2010-2018 (Luerdi \& Marisa, 2013), Indonesian Interest in Cooperation with the Czech Republic in the field of Defense 20152018 (Lesmana, 2019), Technology and The Defense Industry: Real Threats, Bad Habits or New Market Opportunities? (Bellais, 2013) (Susdarwono, 2020). 
This research is structured as follows, part 1 is introduction, part 2 is literature review and methodology, part 3 is results and data analysis and part 4 is conclusion.

\section{LITERATURE REVIEW}

Management is the art of getting work done through other people. In modern management theory, it is stated that there are 4 (four) activities to ensure that programs in an organization can be implemented in total, by implementing Plan, Do, Check and Action (PDCA). The PDCA concept is a guideline for every manager for a continuous quality improvement process without stopping but improving to a better state and being carried out throughout the organization (Mamduh, 1997). Problem identification will be solved and the causes are sought to determine corrective action and must always be based on facts. PDCA is used to optimize the role of the defense industry so that it is able to support the needs of the Navy's defense equipment in a timely and quality manner.

Good strategic management can lead organizations to be able to implement their strategies through program planning, budgeting processes, performance management systems, changes to organizational structures, and program and project management (Rastislav \& Silvia, 2015). In addition, strategic management theory can be related to a strategic plan that is carried out to plan a strategy in making decisions in order to realize a desired goal (Ersoz \& Karaman, 2011).

Another definition of strategic management is a series of fundamental decisions and actions made by top management and implemented by all levels of an organization in order to achieve the goals of the organization. The importance of a strategic plan in advancing the national defense industry, so that the best and appropriate steps can be carried out together (Jang, 2015). In determining the strategy based on the potential factual conditions and problems as described above, the technique used is to look for a cross strategy from the four SWOT factors above, namely(Syahtaria, 2019):

- S-O Strategy: A strategy designed to take advantage of all strengths and optimize existing opportunities;

- ST Strategy: A strategy designed to utilize all strengths in tackling existing threats;

- W-O Strategy: Strategies to take advantage of opportunities optimally to overcome their weaknesses;

- W-T Strategy: Strategy to overcome weaknesses and eliminate threats that arise.

Human resource management is a science or a way of how to manage the relationship and the role of resources (labor) owned by individuals efficiently and effectively and can be used optimally in achieving the goals with the company, employees and society to be maximized(Hamid, 2013). Quality human resources can be achieved through the formation of human capital (human capital). The formation of human capital is an effort to obtain a number of people who have strong characters so that they can be used as important capital in development. This character can be in the form of skill level and community education level. This has been stated in the Superior Performance Assessment Criteria (KPKU) for SOEs, including PT. PAL.

Risk management is a structured approach/methodology in managing uncertainty related to threats. The objective of implementing risk management is to reduce the various risks associated with the selected area to a level that is acceptable to the community (Tehankowa, 2002). PT. PAL must apply it to decide the type of work to be carried out based on a risk management analysis, so that losses do not occur in the future. In its development, the risks discussed in risk management can be classified into: (1) Operational Risk; (2) Hazard Risk; (3) Financial Risk; (4) Strategic Risk. ISO 31000:2009 related to risk management provides principles, frameworks, and risk management processes that can be used as a risk management architecture in an effort to ensure the implementation of effective risk management.

Indonesian National Resilience is the dynamic condition of the Indonesian nation which includes all aspects of integrated national life, contains tenacity and resilience which contains the ability to develop national strength, in facing and overcoming all challenges, threats, 
obstacles and disturbances both coming from outside and from within, to guarantee the identity, integrity, survival of the nation and state as well as the struggle to achieve its national goals(Defense, 2021).

The essence of Indonesia's national resilience is the tenacity and resilience of the nation that contains the ability to develop national strength, to be able to ensure the survival of the nation and state in achieving national goals. Meanwhile, the essence of the conception of Indonesia's national security is the regulation and implementation of welfare and security in a balanced, harmonious, and harmonious manner in all aspects of national life.

Based on an understanding of the relationship between humans and their natural surroundings in aspects of national life, several mappings were obtained on three relatively static gatras (Trigatra), namely geography, natural resources and population, while based on an understanding of human relations in social life, an agreement was obtained that in the conception of Resilience Nationally, all aspects of national life are mapped into five dynamic social lines (Pancagatra), which are considered dominant, namely the ideological line, the political line, the economic one, the socio-cultural line, the defense and security line. The three natural gatras (Trigatra) when combined with the five social gatras (Pancagatra) will of course become eight gatras (Astagatra) which are a comprehensive mapping model of the national life system of the Indonesian nation as a unitary state. These eight gatras (Astagatra) are complete and integrated with each other to form the behavior of the people of the nation and state.

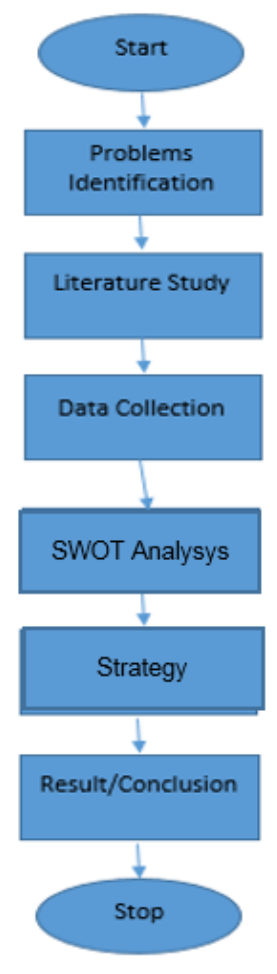

Figure 1 - Research flow

\section{METHODS OF RESEARCH}

The approach used in this study is a mixed method. This combination is done to answer research questions that cannot be fully answered by quantitative or qualitative approaches. Mixed research is a research approach that combines qualitative research with quantitative research. Mixed research is also called a combination research (mixed methods) is a research method that combines or combines quantitative methods with qualitative methods to be used together in a research activity, in order to obtain more comprehensive, valid, reliable and objective data. These methods may involve intermediate methods, which establish procedures for collecting qualitative and quantitative data, such as surveys and in-depth interviews. Likewise, the method used in this study is an intermediate method, research data is collected by researchers by conducting indepth interviews with informants and conducting surveys in the form of questionnaires distributed to other respondents.

SWOT analysis is used to determine strategy criteria that can be done by collecting data using interviews and Focus Group Discussions. The Borda analysis method is used to rank the strategy criteria that have been obtained through the SWOT process so that strategic priorities can be seen that can be taken with the questionnaire data collection method and then with the Balance Scorecard technique, the strategic goals and targets can be determined from the strategy used.

\section{RESULTS AND DISCUSSION}

This research was carried out from April to August 2020, with resource persons who are very competent in the development of State-Owned Enterprises to support the national defense equipment.

The results can be explained as follows: when the IFAS and EFAS factors have been determined, each factor is given a weight on a scale ranging from 1.0 (most important) to 0.0 
(not important), based on the influence of these factors. The weighting of IFAS and EFAS must not exceed the total score of 1.00. If the total score is less than 1.00 then the number is increased until it reaches a score of 1.00 , and vice versa if the total score is more than 1.00 then it must be reduced until it reaches a score of 1.00. Calculation of the rating for each factor by giving a scale ranging from 4 (outstanding) to 1 (poor) then multiply the weight and rating to obtain a weighting score for each factor whose value varies from 4.0 (outstanding) to 1.0 (poor).

Table 1 - SWOT Table

\begin{tabular}{|c|c|}
\hline STRENGTHS & WEAKNESSES \\
\hline $\begin{array}{l}\text { 1. The number of human resources is large. } \\
\text { 2. Adequate facilities and infrastructure. } \\
\text { 3. The development of technology is quite } \\
\text { rapid. } \\
\text { 4. Creating superior human resources }\end{array}$ & $\begin{array}{l}\text { 1. The quality of human resources is limited. } \\
\text { 2. The decline in the ability of infrastructure } \\
\text { for the production of defense equipment. } \\
\text { 3. Limited ability to absorb technology. }\end{array}$ \\
\hline OPPORTUNITIES & THREATS/ANCAMAN \\
\hline $\begin{array}{l}\text { 1. Increased defense budget. } \\
\text { 2. Abundant natural resources. } \\
\text { 3. Advances in communication and } \\
\text { information technology. }\end{array}$ & $\begin{array}{l}\text { 1. The Covid-19 pandemic. } \\
\text { 2. Theft of natural resources. } \\
\text { 3. Negative influence of technology on the } \\
\text { younger generation. }\end{array}$ \\
\hline
\end{tabular}

Table 3 - EFAS Factors

\begin{tabular}{|c|c|c|c|c|}
\hline EFAS FACTORS & WEIGHT & RATE & SCORE & DESC \\
\hline \multicolumn{5}{|l|}{ (OPPORTUNITIES) } \\
\hline 1. Increased defense budget & $+0,20$ & 3 & $+0,60$ & \\
\hline $\begin{array}{l}\text { 2. Abundant natural } \\
\text { resources }\end{array}$ & $+0,30$ & 2 & $+0,60$ & \\
\hline $\begin{array}{l}\text { 3. Advances in } \\
\text { communication and } \\
\text { information technology. }\end{array}$ & $+0,20$ & 2 & $+0,40$ & \\
\hline Jumlah & $+0,70$ & & $+1,60$ & \\
\hline \multicolumn{5}{|l|}{ (THREATS) } \\
\hline $\begin{array}{l}\text { 1. The quality of human } \\
\text { resources is limited }\end{array}$ & $+0,10$ & 3 & $+0,30$ & \\
\hline $\begin{array}{l}\text { 2. The decline in the ability } \\
\text { of infrastructure for the } \\
\text { production of defense } \\
\text { equipment }\end{array}$ & $+0,10$ & 2 & $+0,20$ & \\
\hline \multirow[t]{2}{*}{$\begin{array}{l}\text { 3. Limited ability to absorb } \\
\text { technology }\end{array}$} & $+0,10$ & 2 & $+0,20$ & \\
\hline & $+0,30$ & & $+0,70$ & \\
\hline $\begin{array}{r}\text { RESULT OPPOTUNITIES : } \\
\text { THREATS }\end{array}$ & $+1,00$ & & $+2,30$ & \\
\hline
\end{tabular}

Table 2 - IFAS Factors

\begin{tabular}{|c|c|c|c|c|}
\hline IFAS FACTORS & WEIGHT & RATE & SCORE & DESC \\
\hline \multicolumn{5}{|l|}{ (STRENGTHS) } \\
\hline $\begin{array}{l}\text { 1. The number of human } \\
\text { resources is large }\end{array}$ & $+0,20$ & 3 & $+0,60$ & \\
\hline $\begin{array}{l}\text { 2. Adequate facilities and } \\
\text { infrastructure }\end{array}$ & $+0,20$ & 2 & $+0,40$ & \\
\hline $\begin{array}{l}\text { 3. The development of } \\
\text { technology is quite rapid. }\end{array}$ & $+0,20$ & 2 & $+0,40$ & \\
\hline $\begin{array}{l}\text { 4. Creating superior human } \\
\text { resources }\end{array}$ & $+0,10$ & 2 & $+0,20$ & \\
\hline Jumlah & $+0,70$ & & $+1,60$ & \\
\hline \multicolumn{5}{|l|}{ (WEAKNESS) } \\
\hline $\begin{array}{l}\text { 1. The quality of human } \\
\text { resources is limited }\end{array}$ & $+0,10$ & 3 & $+0,30$ & \\
\hline $\begin{array}{l}\text { 2. The decline in the ability } \\
\text { of infrastructure for the } \\
\text { production of defense } \\
\text { equipment }\end{array}$ & $+0,10$ & 2 & $+0,20$ & \\
\hline \multirow[t]{2}{*}{$\begin{array}{l}\text { 3. Limited ability to absorb } \\
\text { technology }\end{array}$} & $+0,10$ & 2 & $+0,20$ & \\
\hline & $+0,30$ & & $+0,70$ & \\
\hline $\begin{array}{r}\text { RESULT STRENGTH : } \\
\text { WEAKNESS }\end{array}$ & $+1,00$ & & $+2,30$ & \\
\hline
\end{tabular}

Table 4 - Quadrant Calculation

\begin{tabular}{|c|l|c|l|c|}
\hline NO & INTERNAL & SCORE & EKSTERNAL & SCORE \\
\hline 1 & Strengths & 1,60 & Opportunities & 1,60 \\
\hline 2 & Weakness & 0,70 & Threats & 0,70 \\
\hline & & 0,90 & & 0.90 \\
\hline
\end{tabular}

After calculating the influencing factors from internal and external, the selected quadrant results are obtained which become the strategy to obtain the selected quadrant results which will be a strategy to be used as problem solving as shown in the SWOT quadrant matrix image below.

Based on the results of the SWOT analysis calculation, the selected quadrant is quadrant one which has an aggressive strategy, namely by maximizing strengths to take full advantage of opportunities. Below is a table of policy strategy priorities to determine the combination of selected strategies. Table 5 serves to determine the chosen strategy by adding up the Strength $(\mathrm{S})$ score with Opportunity $(\mathrm{O})$. 
Based on the results of the SWOT analysis calculation, the selected quadrant is quadrant one which has an aggressive strategy, namely by utilizing all strengths to seize and take advantage of opportunities as much as possible. Below is a SWOT matrix that will be used to determine the strategy combination.

Table 5 - SWOT Quadrant

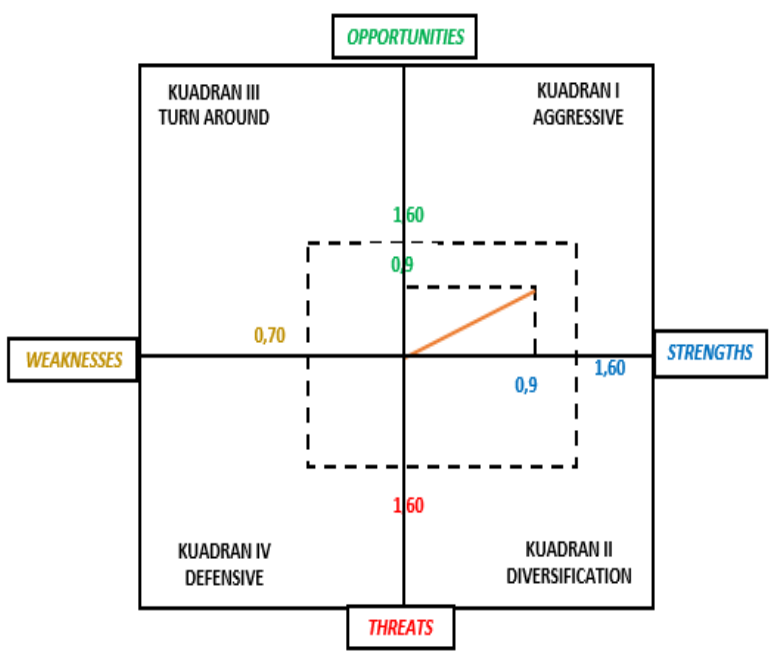

Table 6 - Policy Strategy Priorities

\begin{tabular}{|c|c|c|c|c|c|}
\hline NO & STRATEGY SO & SCORE S & SCORE O & AMOUNT & PRIORITY \\
\hline 1 & $\mathrm{~S} 1+\mathrm{O} 1$ & 0,2 & 0,2 & $\mathbf{0 , 4}$ & III \\
\hline 2 & $\mathrm{~S} 1+\mathrm{O} 2$ & 0,2 & 0,3 & $\mathbf{0 , 5}$ & II \\
\hline 3 & $\mathrm{~S} 1+\mathrm{O} 3$ & 0,2 & 0,3 & $\mathbf{0 , 5}$ & II \\
\hline 4 & $\mathrm{~S} 2+\mathrm{O} 1$ & 0,1 & 0,2 & $\mathbf{0 , 2}$ & $\mathrm{V}$ \\
\hline 5 & $\mathrm{~S} 2+\mathrm{O} 2$ & 0,1 & 0,3 & $\mathbf{0 , 4}$ & III \\
\hline 6 & $\mathrm{~S} 2+\mathrm{O} 3$ & 0,1 & 0,3 & $\mathbf{0 , 4}$ & III \\
\hline 7 & $\mathrm{~S} 3+01$ & 0,1 & 0,2 & $\mathbf{0 , 3}$ & IV \\
\hline 8 & $\mathrm{~S} 3+\mathrm{O} 2$ & 0,1 & 0,3 & $\mathbf{0 , 4}$ & III \\
\hline 9 & $\mathrm{~S} 3+\mathrm{O} 3$ & 0,1 & 0,3 & $\mathbf{0 , 4}$ & III \\
\hline 10 & $\mathrm{~S} 4+01$ & 0,3 & 0,2 & $\mathbf{0 , 5}$ & I \\
\hline $\mathbf{1 1}$ & $\mathbf{S 4 + 0 2}$ & $\mathbf{0 , 3}$ & $\mathbf{0 , 3}$ & $\mathbf{0 , 6}$ & I \\
\hline 12 & $\mathrm{~S} 4+\mathrm{O} 3$ & 0,3 & 0,2 & $\mathbf{0 , 5}$ & II \\
\hline
\end{tabular}

Based on the analysis from Table 5 above, the priority strategy for determining policy is to rank the highest selected strategy, namely the S4 and $\mathrm{O} 2$ strategy with the following formula: Utilizing all strengths $(S)$ to seize and take advantage of opportunities $(O)$ as much as possible as follows:

- S4: HR Optimization;

- O2: Abundant natural resources.

It is undeniable that the mastery of defense industry technology by PT. PAL Indonesia can really encourage the independence of the nation, so that Indonesia will be able to produce its own defense equipment to protect this beloved country. A series of programs from PT. PAL's strategic plan is part of the company's desire to increase the utilization of PT. PAL's production facilities. The increase in utilization will bring this shipyard to an economy of scale so that the company's profit will increase. However, on the other hand, there are still company constraints, both in terms of finance, human resources, facilities and infrastructure as well as marketing strategies that are not optimal. 
Efforts to overcome these problems, PT. PAL must focus on building ships that have been controlled and have been supported by existing facilities and infrastructure, namely LPD and KCR ships. By focusing on these types of ships, PT. PAL will avoid several problems that might arise if PT. PAL produces submarines and PKR. This will also certainly help in making PT. PAL healthy, especially financial problems.

The submarines produced at PT. PAL are the DSME1400 class submarines. This submarine was produced by PT.PAL in collaboration with Daewo Shipbuilding and Marine Engineering (DSME) from South Korea. The DSME1400 class submarine is a different variant of the U-209 type diesel-electric submarine developed by Germany's Howa Idtswerke-Deutsche Werft (HDW). The facility to build this submarine has been prepared by PT. PAL since receiving the joint section and ToT program for the $1^{\text {st }}, 2^{\text {nd }}$ and $3^{\text {rd }}$ submarine construction projects IDR 1.2 Trillion. This resulted in the facilities and infrastructure to build submarines has not been fully realized. As a result, the progress of the delivery of the $3^{\text {rd }}$ submarine in particular, has been delayed for so long, which is more than 2 years from the plan. The impact is the delay in the fulfillment of the Navy's defense equipment in accordance with the planned MEF.

The challenge ahead is that as the $4^{\text {th }}, 5^{\text {th }}$ and $6^{\text {th }}$ submarine construction contracts have been signed using the PT. PAL consortium pattern with DSME, these facilities must be fulfilled immediately. The delay in the delivery of the $3^{\text {rd }}$ submarine must be a valuable lesson for all parties related to this project, especially the Ministry of SOEs and the Ministry of Finance.PT. PAL targets that the PMN application of IDR 1.29 trillion can be disbursed immediately so that the $5^{\text {th }}$ and $6^{\text {th }}$ submarines can be fully worked on domestically. Thus, in the future, PT. PAL is ready to serve orders from the Indonesian Navy to continue the procurement of submarines until the ideal target of 12 (twelve) units can be met and also exports of submarines to other countries. But more importantly PT. PAL must be able to become a partner of the Indonesian Navy for the maintenance and repair of submarines.

In general, it can be summarized the optimization analysis of PT. PAL through the HR and Infrastructure approach to the preparation of the Indonesian Navy's defense equipment, especially the types of ships built by PT. PAL. In the construction of submarines, efforts can be made to: 1) PT. PAL's human resources to build submarines that are currently running still require further ToT. One of the reasons for the delay in the delivery of the $3^{\text {rd }}$ Submarine is the HR factor. Therefore, the ToT program must continue because the contracts for the construction of the $4^{\text {th }}, 5^{\text {th }}$ and $6^{\text {th }}$ submarines have been signed using the consortium method between PT. PAL and DSME Korea. 2) Facilities and infrastructure to continue the construction of submarines need to be immediately completed according to the PMN plan proposed by PT. PAL. This will have a very big influence in completing the construction of the $4^{\text {th }}, 5^{\text {th }}$ and $6^{\text {th }}$ submarine.

\section{CONCLUSION}

One of the national defense industries that can support the defense forces of the Indonesian Navy is PT. PAL. PT. PAL is expected to assist the Indonesian Navy in the development and maintenance of its defense equipment so that it has authority in the ASEAN region. PT. PAL professionally carries out the mandate as well as the obligation to play an active role in supporting the fulfillment of the needs of the marine defense equipment and as the main guide (lead integrator) of the marine dimension. Existing problems will be addressed, especially the organizational structure so that abuse of authority and violations of good corporate governance (GCG) can be anticipated. Some things that are very much needed in the context of revamping PT. PAL are human resources and facilities and infrastructure. The resolution of PT. PAL's problems is carried out through efforts to improve the competence of Human Resources (HR) and production facilities in the form of facilities and infrastructure. Human Capital Building policies and programs must continue to be socialized and internalized to improve the skills of employees to suit the demands of the times. An assessment of PT. PAL has been carried out by the Ministry of BUMN in 2017 
based on the KPKU as a measuring tool; the results obtained by PT. PAL include BUMN category/level band good performance with a score of 489 .

The diesel electric submarine DSME1400 is the first submarine to be assembled locally at the PT. PAL Surabaya facility. In fact, PT. PAL's human resources are still unable to build submarines independently even though some employees have received training in South Korea. In addition, there are 254 personnel who still have to carry out the TOT program at DSME Korea with a budget of more than USD 5,000,000.00. Facilities and infrastructure to continue the construction of submarines need to be immediately completed according to the PMN plan that has been submitted by PT. PAL.

\section{ACKNOWLEDGMENTS}

This research has been supported by the University of Brawijaya, Mlang, Indonesia.

\section{REFERENCES}

1. Bellais, R. (2013). Technology and The Defenselndustry: Real Threats, Bad Habits or New Market Opprtunities? Journal of Innovation Economics and Management, 59-78.

2. Defense. (2021, April 15). Retrieved from https-uai-ac-id-pertahanan-nonmiliter

3. Defense, M. o. (2014). Book of National Defense Strategy. Jakarta.

4. Djarwono, L. F. (2017). Development of the Indonesian Defense Industry: Towards Fulfillment of the MEF Target or Just Towards Arm Candy. Jurnal Defen Indonesia, 02.

5. Ersoz, F., \& Karaman, A. (2011). Development of Defence Capability from an Innovation Perspective: The Case of Turkey. J. of Economic Cooperation and Development, 19-38.

6. Hamid, J. (2013). Strategic Human Resource Management and Performance:The Universalistic Approach - Case of Tunisia. J. of Business Studies Quarterly, 1556-1567.

7. Hartanto, A. (2013). Study on Defense and Security Alutsista Policy of the Republic of Indonesia. Jakarta: LIPI Press.

8. Hartati, S., \& Muhammad, A. (2014). Indonesian Defense Industry model Concept: A Study Framework for Defense Industry Building. J. of Advanced Manag. Sc., 260-266.

9. Hartati, S., \& Muhammad, A. (2014). Indonesian Defense Industry Model Concept: A Study Framework for Defense Industry Building. Journal of Advanced Management Science, 260-266.

10. Jang. (2015). The Hurdies to Being World Class: Narrative Analysis of the world class university project in Korea.

11. Krisdiono, E. (2019). Regional Empowerment Development Strategy as the Main Task of the Navy in Supporting National Resilience (Case Study of Malang Regency). Malang: Desertasi, Brawijaya University.

12. Lesmana, B. (2019). Indonesian Interest in Cooperation with the Czech Republic in the field of Defense 2015-2018. JOM Fisip, 1-15.

13. Luerdi et al (2013). Cicil Participation iin Military Innovation: Cooperation between the Defense Industry of Indonesia and Turkey 2010-2018. Global Strategis, 17-34.

14. Mamduh. (1997). Management. Jogyakarta.

15. Rastislav, R., \& Silvia, L. (2015). Strategic Management of Business Performance Based on Innovations and Information Support in Specific Conditions of Slovakia. Journal of Competitiveness, 3-21.

16. Sarjito, A. (2018). Effectiveness of Minimum Essential Force Policy Main Components of the Indonesian National Armed Forces Navy. J. of Defense Management, Vol. 4 No. 2.

17. Susdarwono, E. T. (2020). Main Thoughts Regarding Development of Indonesian Defense Industry Independence in Law Number 16 of 2012 concerning the Defense Industry. Journal of lus Constituendum.

18. Syahtaria. (2019). SWOT Application on Determining Shipyard Development Strategies: A Case Study. Journal of ASRO, 1-10.

19. Tehankowa. (2002). Risk Identification-Basic Stage in Risk Management. Environmental and health, 1-11. 